\section{European Bison in Poland}

A RECENT Quarterly Information Bulletin concerning the protection of Nature in Poland records that the herd of bisons living in the forest of Bialowicza has now reached the number of fourteen individuals, of which nine belong to the pure race. These are two adult males, two young males, two adult females and three young ones. The remaining five are hybrids - the fourth generation of a cross between an American bison cow and a European bison bull. Of the present stock, five individuals were bought in 1929, and the remainder were born in Bialowicza, as well as an additional young bull now in the zoological garden at Warsaw.

\section{Announcements}

Sir Lancelot Graham, Secretary to the Government of India Legislative Department since 1924 ; Mr. F. W. Ogilvie, president and vice-chancellor of the Queen's University of Belfast; and Prof. G. G. Turner, professor of surgery in the University of London and director of the Surgical Unit at the British Postgraduate Medical School, have been elected members of the Athenæum under the provisions of Rule II of the Club, which empowers the annual election by the Committee of a certain number of persons of distinguished eminence in science, literature, the arts, or for public service.

Sir George Newman, who has been the chief medical officer of the Board of Education since 1907, and of the Ministry of Health since 1919, will retire on March 31. Dr. Arthur Salusbury MacNalty, a senior medical officer of the Ministry and Deputy to the Chief Medical Officer, has been appointed to succeed Sir George, and Mr. Thomas Carnwath has been appointed deputy to the chief medical officer in succession to Dr. MacNalty.

Ar the annual general meeting of the Geological Society of London held on February 15 the following officers were elected : President, Mr. J. F. Norman Green; Vice-Presidents, Prof. P. G. H. Boswell, Prof. W. S. Boulton, Prof. H. L. Hawkins, Sir Thomas Holland; Secretaries, Prof. W. T. Gordon, Dr. Leonard Hawkes; Foreign Secretary, Sir Arthur Smith Woodward; Treasurer, Mr. F. N. Asheroft; New Members of Council, Mr. A. J. Bull, Dr. R. G. S. Hudson, Prof. H. H. Read, Prof. H. H. Swinnerton, Prof. W. W. Watts.

Mr. A. Coulston Evans, assistant plant pathologist at the Long Ashton Research Station, University of Bristol, has been appointed assistant entomologist at the Rothamsted Experimental Station. Mr. Evans received his training at the Royal College of Science under Profs. Balfour-Browne and J. W. Munro; also at University College, London, under Prof. J. C. Drummond, and the London School of Hygiene and Tropical Medicine under Prof. P. A. Buxton. For about eighteen months, he was in France studying sheep blow-fly under Dr. F. G. Holdaway, Council for Scientific and Industrial Research, Commonwealth of Australia, and since August 1934 has been studying fruit pests at the Long Ashton Research Station.
THE portrait of Lord Rutherford, which is Lord Bledisloe's parting gift to New Zealand, was formally presented to the trustees of the New Zealand National Art Gallery at a reception in Wellington on March 1. The Prime Minister of the Dominion as chairman accepted the gift, and in his address paid eloquent tribute to Lord Rutherford. In referring to this portrait in NATURE of March 2 (p. 334), it was stated that Mr. Oswald Birley's original painting is in the Royal Institution. This is not correct; the portrait hangs in the meeting room of the Royal Society.

WrITING with reference to the article in NATURE of February 23 on "Solid Carbon Dioxide" the general manager of the Carbon Dioxide Company, Ltd., Union Marine Buildings, 11 Dale Street, Liverpool, 2, states that this firm also manufactures solid carbon dioxide, and was, indeed, the first to produce it in Great Britain on a commercial basis. The firm's trade name is 'Cardice'.

The Technical Press, Ltd., of 5 Ave Maria Lane, London, E.C.4, has issued a useful classified catalogue of the technical, scientific and industrial books which it publishes. The titles of technical books on practically all branches of engineering are given. The firm also publishes books on trades and manufactures, arts and handicrafts, and agriculture.

Applicatrons are invited for the following appointments, on or before the dates mentioned :-A temporary assistant entomologist in the Advisory Department (Sugar Beet Pests) of the Department of Agriculture, University of Cambridge-The Secretary (March 13). A lecturer in pathology in the University of Liverpool-The George Holt Professor of Pathology (March 15). An assistant botanist in the Ceylon Rubber Research Scheme-The Secretary, London Advisory Committee for Rubber Research (Ceylon and Malaya), Imperial Institute, London, S.W.7 (March 16). Two women lecturers in geography and in mathematics at Norwich Training CollegeThe Principal (March 16). A principal of the Municipal College of Technology, Belfast--The Director of Education, Education Office, Victoria Street, Belfast (March 20). Two junior scientific officers at the Torry Research Station, Aberdeen-The Establishment Officer, Department of Scientific and Industrial Research, 16 Old Queen Street, Westminster, S.W.1 (March 22). Assistant laboratory worker in the Plant Pathology Departments of the Royal Horticultural Society's Laboratories at Wisley-The Director, Royal Horticultural Society, Wisley, Ripley, Surrey (March 23). A junior research officer at the Veterinary Laboratory, New Haw, Weybridge, Surrey-The Secretary, Ministry of Agriculture and Fisheries, 10 Whitehall Place, London, S.W.1 (March 25). A scientific assistant in the Imperial Bureau of Plant Genetics, School of Agriculture, Cambridge-The Deputy Director (March 31). An assistant mycologist in the Midland Agricultural College, Sutton Bonnington, Loughborough-The Acting Principal. A senior assistant engineer in the Research Department of Electric and Musical Industries, Ltd.-The Employment Department. 